\title{
Long-term Effects of Indirect Hyperbilirubinemia on Auditory and Neurological Functions in Term Newborns
}

\author{
Term Yenidoğanlarda İndirekt Hiperbilirubineminin Issitsel ve \\ Nörolojik Fonksiyonlar Üzerine Uzun Dönem Etkileri
}

\section{Gulser Esen BESLI๑, Fazilet METIN ๑, Mehmet Ateş AKSIT ๑, Sema SALTIK ๑}

\author{
Ethics Committee Approval: This study approved by the CSGB SSK Goztepe Training and Research \\ Hospital, Clinical Studies Ethic Committee, 12 January 1999, 1999/028. \\ Conflict of interest: The authors declare that they have no conflict of interest. \\ Funding: None. \\ Informed Consent: Informed consent was taken from the parents of the patients enrolled in this \\ study.
}

\begin{abstract}
Objective: The aim of this study was to investigate the long-term effects of hyperbilirubinemia on neurological and hearing function in otherwise healthy term newborns with neonatal indirect hyperbilirubinemia.

Method: This study was performed prospectively in 41 term newborns hospitalized for indirect hyperbilirubinemia. Patients with no signs of hemolysis were categorized in 3 groups based on stabil levels as sTB $<20 \mathrm{mg} / \mathrm{dl}, 20-24.9 \mathrm{mg} / \mathrm{dl}$, and $=>25 \mathrm{mg} / \mathrm{dl}$. Patients with total bilirubin level =>20 mg/dl and hemolytic disease were classified as the fourth group. The relationship between maximum sTB level, duration of exposure to sTB levels $>20 \mathrm{mg} / \mathrm{dl}$ and etiology of jaundice with neurological and auditory functions was investigated. Detailed neurological examination, Denver II developmental screening test and hearing tests (otoacoustic emissions, $O A E$ and auditory brainstem responses, $A B R$ ) were performed to all patients between 18-24 months of age.

Results: Neurodevelopmental disorder was found in 5 (12.2\%) patients. Hemolytic disease was detected in two of these patients. Hearing loss was found in 4 (9.8\%) of the patients. Two of these patients had auditory neuropathy spectrum disorder and the other two had cochlear hearing loss. The sTB levels of all these patients were above $25 \mathrm{mg} / \mathrm{dl}$. No neurological disorder or hearing loss was found in the patients who had stabil of $<25 \mathrm{mg} / \mathrm{dl}$. Exposure time to sTB levels above $20 \mathrm{mg} / \mathrm{dl}$ was significantly longer in patients with neurological dysfunction and pathologic ABR results (p:0.007, p:0.007; $p<0.05$ ).

Conclusion: This study demonstrates that kernicterus may develop in term newborns with severe hyperbilirubinemia (sTB $>25 \mathrm{mg} / \mathrm{dl}$ ) without any finding of significant hemolysis. Not only the bilirubin level but also the duration of exposure to high bilirubin levels may be effective in the development of bilirubin neurotoxicity. The high rate of hearing loss in our patients emphasizes the importance of screening for infants with severe hyperbilirubinemia using comprehensive auditory evaluation for early diagnosis of possible hearing loss.
\end{abstract}

Keywords: Term neonates, hyperbilirubinemia, neurotoxicity, auditory neuropathy, auditory brainstem responses

Öz

Amaç: Bu çalışmada, neonatal indirekt hiperbilirubinemi dışında başka sorunu olmayan term yenidoğanlarda, hiperbilirubineminin nörolojik gelişim ve işitme fonksiyonu üzerinde uzun dönem etkilerinin arastırılması amaçlanmıștır.

Yöntem: Bu çalışma, indirekt hiperbilirubinemi nedeniyle yatırılarak tedavi edilen 41 term yenidoğanda ileriye dönük olarak gerçekleştirilmiştir. Hemoliz bulgusu saptanmayan hastalar sTB <20 mg/dl, $20-24.9 \mathrm{mg} / \mathrm{dl}$, $=>25 \mathrm{mg} /$ dl olarak 3 gruba ayrılmiştır. Hemolitik hastalık saptanan ve $s T B=>20 \mathrm{mg} /$ dl olan hastalar 4 . grup olarak belirlenmiștir. Maksimum sTB düzeyi, sTB $>20 \mathrm{mg} / \mathrm{dl}$ üzerinde kalma süresi ve sarılık etyolojisi ile nörolojik ve işitsel fonksiyonlar arasındaki ilişki incelenmiștir. Tüm olgulara 18-24. aylar arasında ayrıntılı nörolojik muayene, Denver II gelişimsel tarama testi ve işitme testleri (otoakustik emisyon, OAE ve işitsel beyin sapı cevapları, $A B R$ ) incelemesi yapılmıştır.

Bulgular: Hastaların 5 'inde $(\% 12,2)$ nörolojik gelişim bozukluğu saptanmış olup, bu hastaların sadece ikisinde hemolitik hastalık mevcuttu. Hastaların 4 'ünde $(\% 9,8)$ ișitme kaybı tespit edilmiștir. Bu hastaların ikisi issitsel nöropati spektrum bozukluğu, diğer ikisi ise koklea kaynaklı sensorinöral işitme kaybı olarak değerlendirilmistir. Nörolojik ya da issitsel bozukluk saptanan hastaların hepsinde maksimum sTB düzeyi 25 $\mathrm{mg} / d l$ 'nin üzerinde bulunmuştur. Maksimum sTB düzeyi $25 \mathrm{mg} / \mathrm{dl}$ 'nin altındaki hastaların hiçbirinde nörolojik ya da işitsel bozukluk saptanmamıştır. Nörolojik disfonksiyon ve ABR patolojisi saptanan olguların 20 mg/dl'nin üzerinde sTB düzeylerine maruz kalma süresi, diğer hastalardan anlamlı uzun bulunmuştur (sirasiyla p:0,007, p:0,007; $p<0,05$ ).

Sonuc: Bu calıșma, ciddi hiperbilirubinemisi (sTB>25 mg/dl) olan, ancak belirgin hemoliz bulgusu olmayan term bebeklerde de kernikterus gelișebileceğini; bilirubin nörotoksisitesi gelișmesinde sadece bilirubin düzeyinin değil, yüksek bilirubin düzeylerine maruz kalma süresinin de etkili olabileceğini göstermektedir. Hastalarımızda saptanan yüksek işitme kaybı oranı, ciddi hiperbilirubinemisi olan term yenidoğanların olası işitme kayıplarının erken tanısı için kapsamlı işitme taraması yapılmasının önemini vurgulamaktadır.

Anahtar kelimeler: Term yenidoğan, hiperbilirubinemi, nörotoksisite, işitsel nöropati, issitsel beyin sapı cevapları

(c) Copyright Istanbul Medeniyet University Faculty of Medicine. This journal is published by Logos Medical Publishing.

Licenced by Creative Commons Attribution-NonCommercial 4.0 International (CC BY-NC 4.0)
Received: 20 November 2019

Accepted: 2 January 2020

Online First: 28 February 2020

Corresponding Author:

G.E. Besli

ORCID: 0000-0001-6837-5384

Istanbul Medeniyet University Faculty of Medicine Goztepe Training and Research Hospital Department of Pediatrics, Istanbul, Turkey

besliesen@gmail.com

F. Metin

ORCID: 0000-0002-2360-7222

Erdem Hospital Camlica, Clinics of Neonatology, Istanbul, Turkey

M.A. Akșit

ORCID: 0000-0001-9241-999X Near East University Faculty of Health Sciences Department of Audiology, Lefkosa, Turkish Republic of Northern Cyprus

S. Saltık

ORCID: 0000-0002-6749-5795

Istanbul Cerrahpasa University, Department of Pediatric Neurology, Istanbul, Turkey 


\section{INTRODUCTION}

Neonatal indirect hyperbilirubinemia is one of the most common problems of the newborn period and has mostly a benign course. The risk of neurotoxicity due to severe neonatal hyperbilirubinemia has been known for many years ${ }^{1}$. Since the early 1990s, it has been shown that the risk of kernicterus is much lower in healthy, term infants who have not hemolysis compared to those who have. and serum total bilirubin (STB) limits have been drawn up in the treatment of these infants. However, kernicterus has been increasingly reported in healthy, predominantly breastfed term and near-term newborns with hyperbilirubinemia in the years following the application of more moderate treatment approaches ${ }^{2}$. The most important factors that increase the risk of bilirubin neurotoxicity include isoimmune hemolytic disease, glucose-6-phosphate dehydrogenase deficiency, prematurity, low birth weight, hypercarbia, sepsis, acidosis, asphyxia and hypoalbuminemia. Infants with these risk factors may develop severe hyperbilirubinemia despite appropriate monitoring and treatment ${ }^{1,3,4}$. Therefore, treatment guidelines for newborns with hyperbilirubinemia have been updated since 2004. The limits of phototherapy and exchange transfusion were re-determined using the bilirubin nomograms, which were established according to STB levels, gestational age, postnatal age, risk factors, and duration of postnatal period in hours ${ }^{3,5,6}$. Nevertheless, severe hyperbilirubinemia and bilirubin toxicity may develop in term, breast-fed infants who do not suffer from hemolytic disease. It is not clear how and how often many newborns with similar bilirubin levels are protected from bilirubin toxicity ${ }^{1,2,4}$. It is thought that some unknown stressors and genetic predisposition may increase the risk of toxicity ${ }^{5,7}$. The effect of exposure to high bilirubin levels on the development of kernicterus is also unknown ${ }^{1}$.

Today, although less often, bilirubin encephalopathy and kernicterus continue to be clinical conditions that are still encountered in Turkey and all over the world. Kernicterus is one of the major causes of cerebral palsy, hearing loss, and developmental disorders in children ${ }^{3-6}$. While kernicterus may develop later in infants with hyperbilirubinemia who have no signs of acute bilirubin encephalopathy during the neonatal period, the prognosis of patients in whom development of bilirubin toxicity is suspected can only be determined during long-term follow-up ${ }^{4,7}$. Therefore, long-term follow-up of infants with hyperbilirubinemia in terms of bilirubin toxicity is of great importance for early detection and treatment of possible disorders.

The aim of this study was to investigate the longterm effects of hyperbilirubinemia in term neonates with regard to auditory functions and neurological development, and to investigate the relationship between STB levels and duration of exposure to high bilirubin levels with auditory and neurological dysfunction.

\section{MATERIALS and METHODS}

The study was approved by the local Ethics Committee (Date: 12.01.1999, Number:1999/028). Informed consent was taken from the parents of the patients enrolled in this study.

\section{Study Population and Setting}

The study was conducted prospectively on 41 out of 207 patients with the diagnosis of hyperbilirubinemia who were hospitalized at a tertiary care hospital and met the inclusion criteria within a period of six months. Inclusion criteria were as follows: gestational age, $\geq 37$ weeks, birth weight, $\geq 2500$ g; sTB levels above physiological limits that required treatment; absence of: asphyxia, birth trauma, metabolic disorders (hypoglycemia, hypocalcemia, acidosis, electrolyte disorder and hypoalbuminemia); neonatal infections (sepsis, meningitis and pneumonia); intrauterine infection, congenital metabolic disease, congenital anomaly, pathologies that may lead to neonatal cerebral damage such as intracranial hemorrhage; 
and family history of hearing loss, and suitability for long term follow-up (Figure 1). Family consent was obtained for all the cases. In order to compare the hearing test results, a control group consisting of 12 children between 18-24 months of age with no risk factors for neurological development and hearing loss, especially jaundice, was formed.

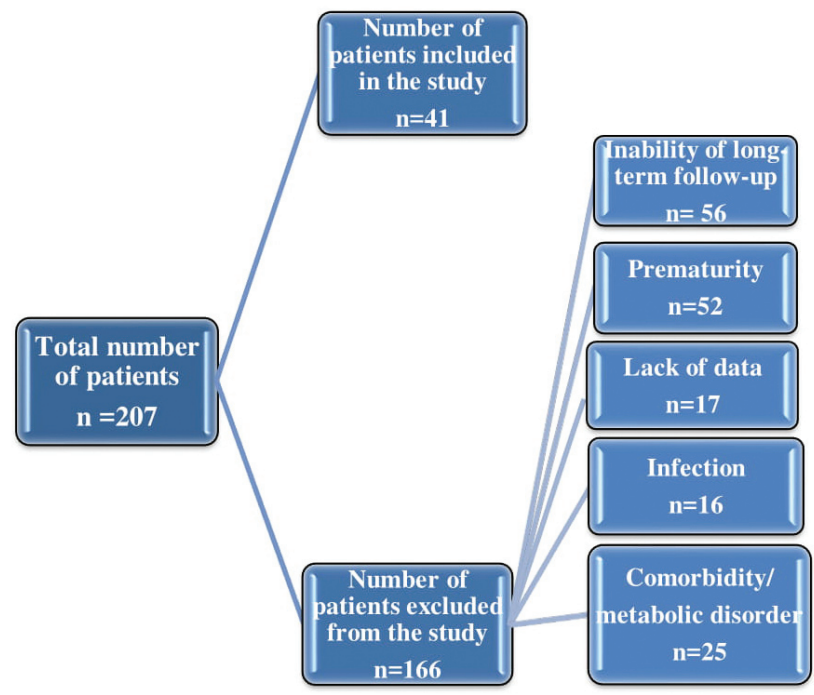

Figure 1. Study population.

A jaundice follow-up form was formulated and the antenatal and natal characteristics, the day when jaundice was noticed, the first feeding time, feeding type and frequency, time to meconium passage, physical examination findings at the time of admission, laboratory tests, treatment method and duration, and etiology of jaundice were recorded for all cases. Maternal and infant blood groups, direct Coombs test, complete blood count, reticulocyte count, and quantitative glucose-6-phosphate dehydrogenase enzyme measurements were performed in all infants. Blood smear was stained with May-Gruenwald-Giemsa dye and erythrocyte morphology was evaluated. Serum total bilirubin measurements were performed by spectrophotometric method and were followed at 4 hours intervals unless more frequent measurements were required. The presence of jaundice within the first 24 hours, low hematocrit value, reticulocytosis, direct Coombs test positivity, and erythrocyte morphology supporting hemolysis suggested the diagnosis of hemolytic disease.

The study group was divided into 4 groups based on the presence of maximum STB and hemolysis. Patients without any signs of hemolysis and unidentified jaundice etiology were grouped based on sTB levels as sTB $<20 \mathrm{mg} / \mathrm{dl}$ (Group I), 20-24.9 $\mathrm{mg} / \mathrm{dl}$ (Group II), and $\geq 25 \mathrm{mg} / \mathrm{dl}$ (Group III). Patients with total bilirubin level of $\geq 20 \mathrm{mg} / \mathrm{dl}$ and hemolytic disease were identified as Group IV. In the study group, all cases underwent detailed neurological examinations between postnatal $18-24^{\text {th }}$ months (mean $21.02 \pm 1.67$ months) by a pediatric neurologist. Furthermore, Denver II developmental screening test, auditory brainstem responses (ABRs) and otoacoustic emission tests (OAEs) were performed. Prior to evaluation process using $A B R$ and $O A E$ tests, all subjects were examined by an otorhinolaryngologist to exclude possible middle ear pathologies. Impedance audiometry test was performed in patients as recommended by the otorhinolaryngologist and in patients with pathological OAE/ABR test results. Cranial magnetic resonance imaging (MRI) was performed to show the neuroanatomic localization of bilirubin toxicity in cases with pathological $A B R$ results and/or neurological findings.

\section{Measurements}

Evaluation of Hearing acuity (ABR, OAE and tympanometry) was performed in the soundproof room at an Audiological Diagnostic Center. All audiological assessments and interpretations were done by an audiologist (Ph.D). Danplex-TYMP-87-Clinical-Middle-Ear-Analyzer was used for impedance audiometry test. Auditory Brainstem responses were recorded by Amplaid MK12 electrophysiological measuring instrument. Silver electrodes were placed at the midline scalp border (as positive), ipsilateral earlobe (as negative) and between two eyebrows (as ground). Electrode impedances were not allowed to exceed $5 \mathrm{Kohm}$. Recordings were obtained monoaurally using 100 microsecond click acoustic stimuli. The stimuli were delivered 
through TDH 49 headphones. In the diagnostic test, recurrent 1000 stimuli in alternate polarity with $11 / \mathrm{sec}$ rate at $70 \mathrm{dBnHL}$ intensity were used. If wave $V$ was not seen clearly, test was repeated with rarefaction/condensation polarity at the same intensity level to record cochlear microphonics. If wave $\mathrm{V}$ was recorded clearly then level of 60 and $30 \mathrm{~dB} \mathrm{nHL}$ were also controlled with $21 / \mathrm{sec}$ rate stimulus. Each condition was recorded with double traces.

Otoacoustic emissions were obtained by "transient evoked otoacoustic emission, TEOAE” technique. The test was performed using Otodynamics' ILO 96 (version 5) equipment. In the Quickscreen mode, $80 \mathrm{~dB}$ pe SPL click stimulus was applied in a $2.5-12.5 \mathrm{~ms}$ time window $( \pm 6)$. The stimulus frequency was $80 / \mathrm{sec}$ and a total of 260 click stimuli were used. The test results were evaluated as "passed" and "failed". Signal-to-noise ratio of 3 $\mathrm{dB}$ or higher in at least 3 of the $0.8 \mathrm{kHz}, 1.6 \mathrm{kHz}$, $2.4 \mathrm{kHz}, 3.2 \mathrm{kHz}$ and $4.0 \mathrm{kHz}$ frequency bands was considered as "passed".

The Denver II Developmental Screening Test was applied to all subjects by the Denver II Developmental Screening Test certified researcher. Test results were evaluated as "normal, suspicious, abnormal" and the suspicious tests were repeated 3 months later.

\section{Statistical Analyses}

ABR I, III, V absolute wave latencies and interpeak intervals of I-III, III-V and I-V waves between the study and the control groups were compared. The relationship between maximum STB level and duration of exposure to sTB levels above $20 \mathrm{mg}$ / dl with neurological dysfunction and ABR results was investigated.

SPSS (Statistical Package for Social Sciences) for Windows 7.0 was used for statistical analysis. Oneway Anova, Kruskal Wallis Test, Mann Whitney $\mathrm{U}$ test and Spearman correlation analysis were used for the comparison of quantitative data as well as descriptive statistical methods (mean, standard deviation). The Fisher Exact chi-square test was used to compare the qualitative data. Results were evaluated at $95 \%$ confidence interval and $p<0.05$ level of significance.

\section{RESULTS}

Of the 41 patients recruited for the study, 23 (56\%) were male and 18 (44\%) were female, with a mean age of $21.02 \pm 1.67$ months. Characteristics of the patients according to the study subgroups (gestational age, birth weight, day of hospitalization, sTB level, hematocrit, reticulocyte values, current age) are shown in Table 1 . ABR audiometry revealed that I, III, V wave absolute latencies and interpeak intervals of I-III, III-V, and I-V waves were not significantly different between the study and the control groups (Table 2). Hearing problem was found in 4 (9.8\%) of 41 patients and Denver II test was evaluated as abnormal in 5 (12.2\%) patients. Various neurological findings were found in all of these patients. All of the patients with neurological disorder and hearing problems were in Groups III and IV, and they were referred to our hospital from rural areas. All of the cases with pathological OAE/ABR results passed the tympanometric test. Static compliances were between 0.22 and 0.56 cc. Relevant detailed data are presented in Table 3. Infants in Groups I and II had no neurological dysfunction or hearing problem (no hemolysis and sTB $<25$ $\mathrm{mg} / \mathrm{dl})$. There was a significant relationship between the presence of neurological findings and the pathological ABR results $(p<0.001$, Table 4$)$. The maximum STB of the patients with neurological dysfunction and ABR pathology was found to be significantly higher than the other patients (p:0.001 and 0.002, respectively; Table 5). Similarly, in patients with neurological dysfunction and pathologic ABR findings, duration of exposure to sTB levels above $20 \mathrm{mg} / \mathrm{dl}$ was significantly longer than the other patients ( $p: 0.007$ and 0.007, respectively; Table 6). 
Table 1. Characteristics of the patients by groups.

\begin{tabular}{|c|c|c|c|}
\hline & Group & $\begin{array}{l}\text { Number of } \\
\text { Patients (n) }\end{array}$ & $\begin{array}{l}\text { Mean } \pm \text { Standard } \\
\text { Deviation }\end{array}$ \\
\hline \multirow[t]{5}{*}{ Gestational age (weeks) } & I & 11 & $39.91 \pm 1.30$ \\
\hline & II & 10 & $39.40 \pm 1.08$ \\
\hline & III & 10 & $38.90 \pm 1.60$ \\
\hline & IV & 10 & $40.10 \pm 0.88$ \\
\hline & Total & 41 & $39.59 \pm 1.28$ \\
\hline \multirow[t]{5}{*}{ Birth weight (grams) } & I & 11 & $3372.90 \pm 541.00$ \\
\hline & II & 10 & $3255.00 \pm 559.99$ \\
\hline & III & 10 & $3115.00 \pm 274.92$ \\
\hline & IV & 10 & $3124.50 \pm 360.87$ \\
\hline & Total & 41 & $3220.60 \pm 449.21$ \\
\hline \multirow[t]{5}{*}{ Day of hospitalization } & I & 11 & $6.27 \pm 3.90$ \\
\hline & II & 10 & $5.00 \pm 2.62$ \\
\hline & III & 10 & $6.60 \pm 1.43$ \\
\hline & IV & 10 & $6.00 \pm 5.19$ \\
\hline & Total & 41 & $5.98 \pm 4.50$ \\
\hline \multirow[t]{5}{*}{ Maximum TB* level (mg/dl) } & I & 11 & $18.23 \pm 1.11$ \\
\hline & II & 10 & $22.91 \pm 0.59$ \\
\hline & III & 10 & $30.92 \pm 7.94$ \\
\hline & IV & 10 & $31.69 \pm 6.70$ \\
\hline & Total & 41 & $25.75 \pm 7.60$ \\
\hline \multirow[t]{6}{*}{$\mathrm{TB}^{*}>20 \mathrm{mg} / \mathrm{dl}$ duration (hours) } & I & - & - \\
\hline & II & 10 & $7.95 \pm 4.42$ \\
\hline & III & 10 & $16.15 \pm 5.61$ \\
\hline & IV & 10 & $14.75 \pm 7.32$ \\
\hline & Total & 30 & $12.95 \pm 6.76$ \\
\hline & I & 11 & $56.27 \pm 5.48$ \\
\hline \multirow[t]{5}{*}{ Hematocrit (\%) } & II & 10 & $52.60 \pm 4.62$ \\
\hline & III & 10 & $55.93 \pm 9.36$ \\
\hline & IV & 10 & $49.80 \pm 8.42$ \\
\hline & Total & 41 & $53.71 \pm 7.43$ \\
\hline & $\mathrm{I}$ & 11 & $1.28 \pm 0.65$ \\
\hline \multirow[t]{4}{*}{ Reticulocytes (\%) } & II & 10 & $2.21 \pm 1.48$ \\
\hline & III & 10 & $1.64 \pm 0.78$ \\
\hline & IV & 10 & $7.25 \pm 1.13$ \\
\hline & Total & 41 & $3.05 \pm 2.64$ \\
\hline \multirow[t]{5}{*}{ Current age of the patients (months) } & I & 11 & $21.64 \pm 1.47$ \\
\hline & II & 10 & $21.95 \pm 1.54$ \\
\hline & III & 10 & $20.60 \pm 1.71$ \\
\hline & IV & 10 & $19.85 \pm 1.23$ \\
\hline & Total & 41 & $21.02 \pm 1.67$ \\
\hline
\end{tabular}

${ }^{*} T B=$ Total bilirubin

Table 2. Comparison of Auditory Brainstem Response Wave Latencies (ms) and Interpeak Intervals (ms) Between the Study and Control Groups.

\begin{tabular}{|c|c|c|c|c|c|c|}
\hline & Group I n=11 & Group II $n=10$ & Group III $n=8$ & Group IV $n=8$ & Controls $n=12$ & $\mathbf{p}$ \\
\hline Wave I Latency & $1.68 \pm 0.07$ & $1.68 \pm 0.10$ & $1.69 \pm 0.13$ & $1.72 \pm 0.16$ & $1.63 \pm 0.08$ & 0.698 \\
\hline Wave III Latency & $3.89 \pm 0.16$ & $3.93 \pm 0.09$ & $3.93 \pm 0.15$ & $3.96 \pm 0.12$ & $3.93 \pm 0.10$ & 0.883 \\
\hline Wave V Latency & $5.81 \pm 0.12$ & $5.81 \pm 0.08$ & $5.83 \pm 0.09$ & $5.80 \pm 0.19$ & $5.73 \pm 0.16$ & 0.455 \\
\hline I-III Interpeak interval & $2.20 \pm 0.14$ & $2.25 \pm 0.09$ & $2.23 \pm 0.15$ & $2.24 \pm 0.15$ & $2.29 \pm 0.09$ & 0.584 \\
\hline I-V Interpeak interval & $4.13 \pm 0.10$ & $4.12 \pm 0.14$ & $4.14 \pm 0.09$ & $4.08 \pm 0.19$ & $4.10 \pm 0.14$ & 0.876 \\
\hline III-V Interpeak interval & $1.92 \pm 0.13$ & $1.87 \pm 0.08$ & $1.91 \pm 0.13$ & $1.83 \pm 0.11$ & $1.80 \pm 0.15$ & 0.195 \\
\hline
\end{tabular}


Table 3. Characteristics of the Patients with Neurological Dysfunction and ABR Pathology.

\begin{tabular}{|c|c|c|c|c|c|}
\hline$\frac{\mathscr{m}}{4}$ & 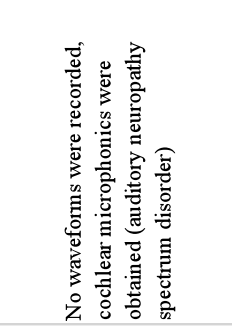 & 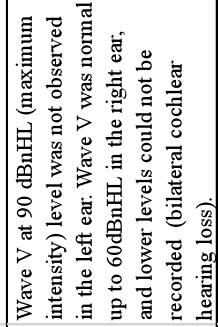 & 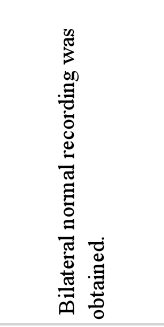 & 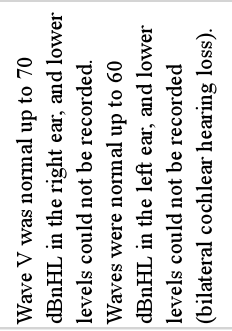 & 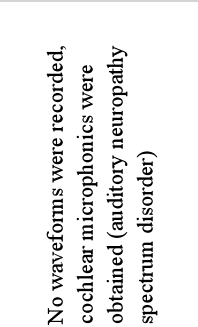 \\
\hline 迳 & 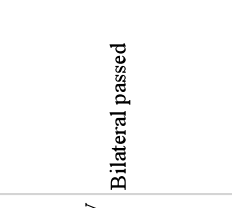 & 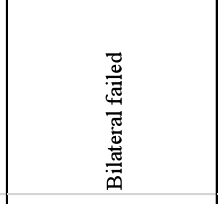 & 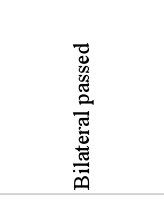 & 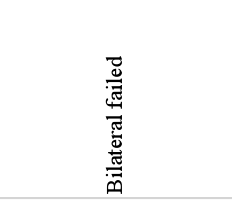 & 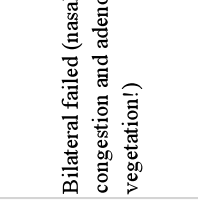 \\
\hline 运 & 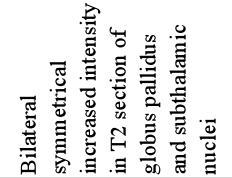 & 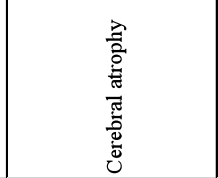 & $\begin{array}{l}\overline{\widetilde{\sigma}} \\
\stackrel{\Xi}{\mathrm{Z}} \\
\end{array}$ & 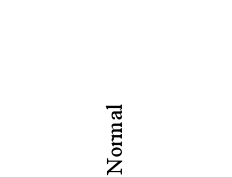 & 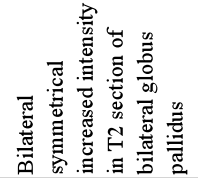 \\
\hline 鴶 & 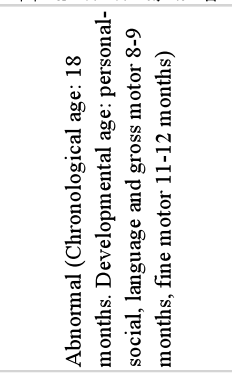 & 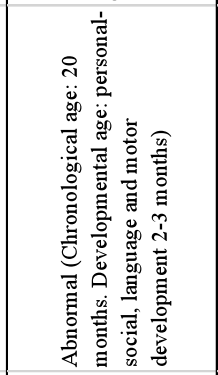 & 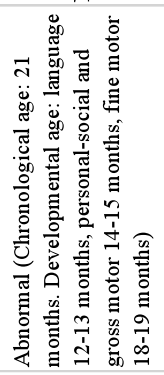 & 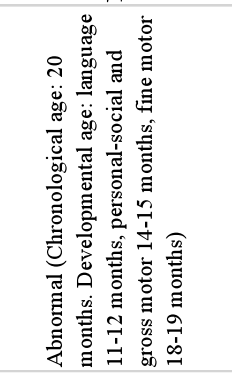 & 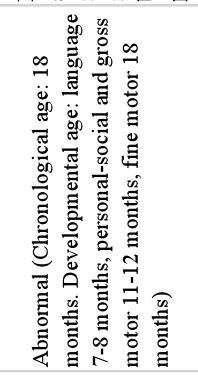 \\
\hline 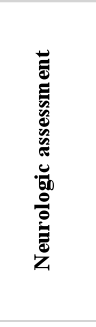 & 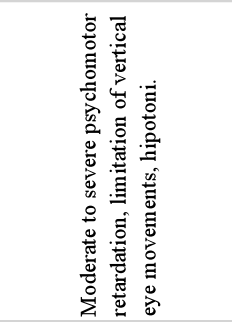 & 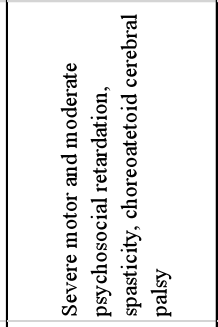 & 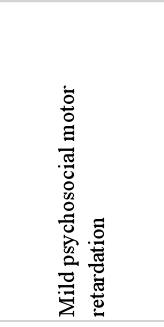 & 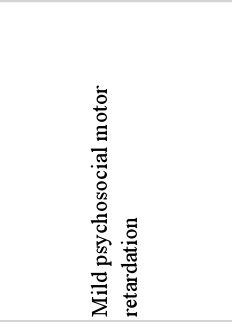 & 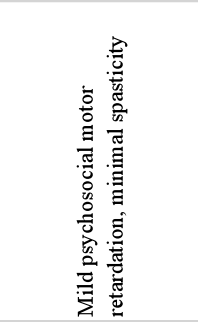 \\
\hline 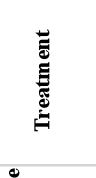 & 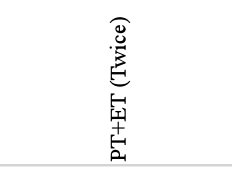 & 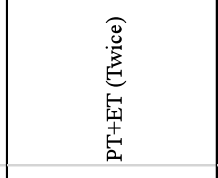 & 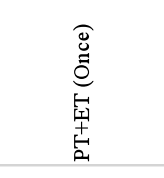 & 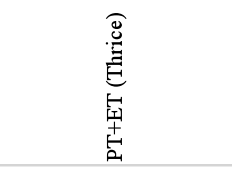 & 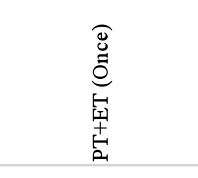 \\
\hline $\begin{array}{ll}0 \\
0\end{array}$ & I & $\tilde{i}_{i}^{n}$ & $\stackrel{\longrightarrow}{1}$ & à & $\stackrel{ }{-1}$ \\
\hline 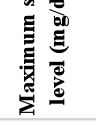 & 䇥 & $\vec{n}$ & के & $\begin{array}{l}0 \\
\dot{f}\end{array}$ & ले \\
\hline t) & 目 & 目 & 目 & z & 2 \\
\hline 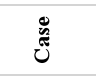 & $\tau$ & N & $m$ & $\nabla$ & in \\
\hline
\end{tabular}


Table 4. Relationship Between Neurological Dysfunction and ABR Results.

\begin{tabular}{lllll}
\hline & \multicolumn{2}{c}{ ABR Result } & & \\
\cline { 2 - 4 } $\begin{array}{l}\text { Neurological } \\
\text { Dysfunction }\end{array}$ & Normal & Pathological & Total & $\mathbf{P}^{*}$ \\
\hline None & $36(87.8 \%)$ & $0(0 \%)$ & $36(87.8 \%)$ & \\
Present & $1(2.4 \%)$ & $4(9.8 \%)$ & $5(12.2 \%)$ & 0.001 \\
Total & $37(90.2 \%)$ & $4(9.8 \%)$ & $41(100 \%)$ & \\
\hline
\end{tabular}

${ }^{*} p<0.001$. ABR; auditory brainstem response
Table 5. Association Between Maximum sTB Level, ABR Results and Neurological Dysfunction.

\begin{tabular}{|c|c|c|c|c|}
\hline & Definition & $\begin{array}{l}\text { Maximum sTB } \\
\text { Level (mg/dl) } \\
\text { Mean+SD }\end{array}$ & $\begin{array}{l}\mathbf{N} \text { of } \\
\text { patients }\end{array}$ & $\mathbf{P}^{*}$ \\
\hline \multirow[t]{2}{*}{ ABR } & Normal & $24.03 \pm 5.29$ & 37 & 0.002 \\
\hline & Pathological & $41.68 \pm 7.66$ & 4 & \\
\hline Neurological & None & $23.87 \pm 5.28$ & 36 & 0.001 \\
\hline Dysfunction & Present & $39.3 \pm 8.52$ & 5 & \\
\hline
\end{tabular}

Table 6. Association Between Duration of Exposure to sTB Levels Above $20 \mathrm{mg} / \mathrm{dl}$ and Neurological Dysfunction and ABR Results.

\begin{tabular}{lllll}
\hline & Definition & Number of Cases $(\mathbf{n})$ & $\begin{array}{l}\text { Duration of Exposure to sTB Levels Above 20 mg/dl } \\
\text { Mean (Hours) } \pm \text { Std. Deviation }\end{array}$ \\
\hline ABR Result & Normal & 26 & $11.48 \pm 5.68$ \\
& Pathological & 4 & $22.50 \pm 5.70$ \\
Neurological & None & 25 & $11.30 \pm 5.72$ \\
Dysfunction & Present & 5 & $21.20 \pm 5.72$ & 0.007 \\
\hline
\end{tabular}

${ }^{*} p<0.01$. sTB; serum total bilirubin, $A B R$; auditory brainstem response

\section{DISCUSSION}

Indirect hyperbilirubinemia is one of the most common problems in the neonatal period and manifests a broad spectrum ranging from a completely harmless physiological process to severe neurotoxicity and brain damage. The first systematic relationship between bilirubin level and neurotoxicity was reported in the early 1950s, and it was shown that the risk of kernicterus increases with the increase in bilirubin levels in infants with hemolytic disease ${ }^{8}$. Ozmert et al. ${ }^{9}$ reported 102 cases with a history of hyperbilirubinemia and aged between 8 and 13 years, and the most prominent kernicterus findings were reported in hemolytic cases with a positive Coombs test. In our study, kernicterus findings were found in five patients (12.2\%). While two of these patients (cases 4 and 5) had severe hyperbilirubinemia with hemolytic disease, the others (cases 1, 2 and 3 ) had no significant hemolysis findings with STB levels of $\geq 25 \mathrm{mg} / \mathrm{dl}$. These findings support the opinion that bilirubin neurotoxicity can develop not only in infants with hemolytic disease but also in healthy, term infants without any significant finding of hemolysis and STB levels above $25 \mathrm{mg} /$ $\mathrm{dl}^{2,10}$. The exact cause of severe hyperbilirubinemia and kernicterus is not known in healthy, term infants without any significant findings of hemolysis. However, severe hyperbilirubinemia is thought to be associated with factors such as early discharge of infants, increase in the risk of dehydration and weight loss due to insufficiently informed mother and breastfeeding problems despite the increase in breast milk feeding frequencies, racial characteristics and genetic predisposition ${ }^{5,7,10}$. On the other hand, it can be misleading to decide whether a baby with jaundice has hemolysis based on routine laboratory methods. A case of kernicterus with no signs of hemolysis other than reticulocytosis has been reported ${ }^{2}$. Anna et al. ${ }^{11}$ found no signs of hemolysis except mildly low hematocrit values in a case of severe hyperbilirubinemia and kernicterus due to sepsis. In our study, although there was no evidence supporting hemolysis in a case with kernicterus (Case 1), the initial hematocrit value at admission to the hospital was 32.3\%, suggesting that a hemolytic process might occur 
which could not be detected by other routine laboratory methods.

To prevent the development of severe hyperbilirubinemia and neurotoxicity after hospital discharge, it is important to establish the sTB percentile values and risk factors for all newborns before they are discharged from the hospital, to monitor them according to risk assessment protocols and to follow the current treatment guidelines ${ }^{3,6}$. However, it is difficult to implement these current treatment guidelines especially in rural areas with low socioeconomic level, where cases with kernicterus are more frequently seen ${ }^{6}$. Therefore, neonatal hyperbilirubinemia remains an important problem with high morbidity and mortality risks, especially in developing countries.

Bilateral sensorineural hearing loss developed at high frequencies has been widely described due to chronic bilirubin encephalopathy. Towards the end of the 1970s, electrophysiological tests such as $A B R$ and OAE have been used to better evaluate cochlear hair cells, $8^{\text {th }}$ nerve and brainstem pathway which allowed a better understanding of the effects of hyperbilirubinemia on hearing function $^{12}$. Although some previous studies argued that the pathology in the auditory tract affects cochlea and/or the $8^{\text {th }}$ nerve without brainstem involvement; more recently, an auditory disorder characterized by normal cochlear functions (as evidenced by the presence of cochlear microphonics in $A B R$ and the normal OAE response) but unresponsive to treatment or severely impaired $A B R$ has been found related to bilirubin toxicity ${ }^{13-16}$. This condition which develops at the retrocochlear (neuronal) level, is now described as auditory neuropathy spectrum disorder (ANSD) ${ }^{4,15,16}$. In series of ABRs, it was shown that ANSD findings can be improved and neuronal damage can be reversible after timely applied phototherapy and exchange transfusion. If irreversible neuronal damage develops due to bilirubin toxicity, permanent hearing loss may occur. This suggests that one of the most susceptible regions to neurotoxicity due to hyperbilirubinemia is the auditory pathway ${ }^{15,17,18}$. In fact, hearing loss may be the only sign of chronic bilirubin encephalopathy ${ }^{4,16}$.

Results of the ABR examinations performed in our study did not reveal any statistically significant difference between the study and the control groups in terms of I, III, V wave latencies and interpeak intervals of I-III, III-V, and I-V waves. However, four patients had hearing loss (9.8\%). While no ABR record was obtained in two of our patients with hearing loss (Cases 1 and 5), the presence of cochlear microphonics suggested the presence of ANSD. In Case 1, bilateral normal response was obtained in $\mathrm{OAE}$, but in Case 5, any $\mathrm{OAE}$ response could not be elicited. However, it was thought that this finding might be related to his adenoid vegetation and nasal congestion. In the other two cases (Cases 2 and 4), the findings of bilateral hearing loss in ABR and lack of response in OAE test were attributed to cochlear hearing loss. It was thought that the toxicity caused by hyperbilirubinemia in the auditory tract may affect both the $8^{\text {th }}$ cranial nerve (retrocochlear region) and hearing cells in the cochlea. This result supports the opinion that screening tests only with $A B R$ or OAE should not be sufficient in infants with a history of severe neonatal hyperbilirubinemia and that $A B R$ and $O A E$ should be performed together ${ }^{16}$. Therefore, it will be possible to identify the localization of the damage to the auditory tract and to develop correct treatment approaches. Patients with ANSD do not usually benefit from hearing aids. In recent years, good results have been reported in patients undergoing cochlear implantation ${ }^{18}$.

In our study, hearing loss rate of $9.8 \%$ found in patients with a history of hyperbilirubinemia was significantly higher compared to the hearing loss rate of $0.1-0.6 \%$ in the normal population ${ }^{19}$. This result emphasizes the importance of $A B R$ screening in newborn with hyperbilirubinemia requiring treatment to detect possible hearing loss at an early stage (especially before 6 months) and to 
prevent irreversible language impairment.

Ogün et al. ${ }^{20}$ did not find any correlation between sTB levels and ABR latencies or thresholds in children aged 24-72 months who had neonatal hyperbilirubinemia (term, sTB $20-24 \mathrm{mg} / \mathrm{dl}$, with no hemolysis). In another study conducted with the similar patient group, any correlation between STB levels and ABR latencies, was not detected. None of the infants had hearing loss, developmental delay or neurological dysfunction ${ }^{21}$. On the other hand, some other studies reported a positive correlation between bilirubin levels and ABR results ${ }^{22-24}$. Ozmert et al. ${ }^{9}$ found that the percentage of abnormal ABR was significantly higher in patients with sTB levels above $20 \mathrm{mg} / \mathrm{dl}$, and the rate of neurological sequelae increased with prolonged exposure to sTB levels above $20 \mathrm{mg} /$ dl. DeVries et al. ${ }^{25}$ reported that the longer the duration of hyperbilirubinemia, the higher the risk of sensorineural hearing loss. In another study, any significant relationship was not found between serum bilirubin levels and IQ, sensorineural hearing loss, and significant neurological disorder after 8 years of follow-up of patients with STB levels of $20 \mathrm{mg} / \mathrm{dl}$. However, a weak relationship between high bilirubin levels and minor neurological dysfunction was found in the same study ${ }^{26}$. In a study performed by Scheidt et al. ${ }^{27}$ involving 27,270 infants, a strong correlation was found between serum bilirubin level and motor development disorder at $8^{\text {th }}$ and $12^{\text {th }}$ months in infants small for their gestational age with low birth weight. In our study, it was determined that the maximum STB levels of the patients with pathologic ABR results and neurological dysfunction were significantly higher than the other patients $(p<0.01)$. There was a positive correlation between the increase in STB levels, pathologic $A B R$ results $(r=0.497 ; p<0.01)$ and neurological dysfunction $(r=0.513 ; p<0.01)$. Similarly, the duration of exposure to STB levels above $20 \mathrm{mg} / \mathrm{dl}$ in patients with neurological dysfunction and pathologic $A B R$ results was found to be significantly longer than those without neurological signs and pathologic ABR results $(p<0.01)$.
These findings suggest that not only the increase in bilirubin levels but also the duration of exposure to high bilirubin levels play an important role in increasing the risk of bilirubin neurotoxicity.

Several studies have investigated whether $A B R$ has a predictive value for neurological dysfunction in patients with neonatal hyperbilirubinemia. Kuriyama et al. ${ }^{28}$ found pathological $A B R$ after treatment in two of $\mathbf{3 0}$ hyperbilirubinemic infants. Neurological evaluation of these infants for one year revealed cerebral palsy in one, and lack of neurological dysfunction in the other patient. In another study, serial ABR recordings performed at 3-month intervals in newborns with a STB level $>20 \mathrm{mg} / \mathrm{dl}$ suggested that persistence of $A B R$ disorders may be a leading symptom of chronic bilirubin encephalopathy ${ }^{29}$. In the study of Ozmert et al. ${ }^{9}$, ABR results were pathological in all patients with significant neurological findings, and in $46.6 \%$ of those with mild neurological findings. The sensitivity and specificity of ABR were found to be $100 \%$ and $81 \%$, respectively in the longterm follow-up of infants with hyperbilirubinemia. In our study, when neurological findings and ABR results were compared, there was a strong relationship between neurological dysfunction and pathological $A B R$ results. However, it should be kept in mind that normal $A B R$ recording can be obtained even in cases with damage to the basal ganglia, since the ABR examination does not provide information on regions above the brainstem. In other words, extrapyramidal findings may develop in patients with normal ABR examination ${ }^{4}$. Therefore, further studies are needed to establish the predictive value of $A B R$ for persistent neurological dysfunction in patients with neonatal hyperbilirubinemia.

Specific anatomical localization of brain damage caused by kernicterus can be detected with cranial MRI. The characteristic findings on MRI are areas of increased intensity in the globus pallidus, subthalamus and hippocampus. This increase in intensity is bilateral, symmetrical and is more 
prominent in $\mathrm{T} 1$ sections in the neonatal period, while it is more clearly observed in T2-weighted sections in the advanced stages. On the other hand, cranial MRI can be normal in patients with chronic bilirubin encephalopathy ${ }^{4,30}$. In our study, in two of the five patients with neurologic findings who underwent cranial MRI examination, increased symmetrical intensity was detected in the T2-weighted section in the basal ganglia (globus pallidus and subthalamic nuclei), whereas MRI imaging was found to be normal in the other three patients.

\section{Limitations of the Study}

This was a single-centered study performed with limited number of patients

\section{CONCLUSION}

This study demonstrates that kernicterus may develop in term newborns with severe hyperbilirubinemia ( $>25 \mathrm{mg} / \mathrm{dl}$ ) without any finding of significant hemolysis. It has been shown that the risk of developing bilirubin neurotoxicity may increase by not only high bilirubin levels, but also by prolonged exposure to high bilirubin levels. In Turkey, newborn hearing screening test has been implemented since 2004 under the national hearing screening program ${ }^{31}$. Infants at risk for hearing loss such as hyperbilirubinemia are referred to audiology clinics for advanced audiological tests after screening tests. The high rate of hearing loss in our patients emphasizes the importance of sophisticated hearing tests for the early diagnosis of possible hearing loss in newborns with severe hyperbilirubinemia.

\section{REFERENCES}

1. Ambalavanan N, Carlo WA. Kernicterus In: Kliegman RM, Stanton BF, St Geme JW, Schor NF (eds). Nelson Texbook of Pediatrics. $20^{\text {th }}$ ed. Philedelphia, PA: Elsevier, 2016:876-80.

2. Maisels MJ, Newman TB. Kernicterus in Otherwise Healthy, Breast-Fed Term Newborns. Pediatrics. 1995;96:730-3.

3. American Academy of Pediatrics Subcommittee on Hy- perbilirubinemia. Management of Hyperbilirubinemia in the Newborn Infant 35 or More Weeks of Gestation. Pediatrics. 2004;114:297-316. [CrossRef]

4. Usman F, Diala UM, Shapiro SM, Le Pichon JB, Slusher TM. Acute bilirubin encephalopathy and its progression to kernicterus: current perspectives. Research and Reports in Neonatology. 2018;8:33-44. [CrossRef]

5. Maisels MJ, Bhutani VK, Bogen D, Newman TB, Stark AR, Watchkoet JFl. Hyperbilirubinemia in the Newborn Infant 35 Weeks' Gestation: An Update With Clarifications. Pediatrics. 2009;124:1193-98. [CrossRef]

6. Coban A, Turkmen M, Gursoy T. Türk Neonatoloji Derneği Yenidoğan Sarılıklarında Yaklaşım, İzlem ve Tedavi Rehberi. Türkiye; 2014. Available at: http=//www.neonatology.org.tr/wp-content/uploads/2019/10/Sarilik.pdf

7. Riordan SM, Bittel DC, Le Pichon JB, et al. A hypothesis for using pathway genetic load analysis for understanding complex outcomes in bilirubin encephalopathy. Front Neurosci. 2016;10:376. [CrossRef]

8. Newman TB, Maisels MJ. Evaluation and treatment of jaundice in the term newborn: A kinder gentler approach. Pediatrics. 1992;89:809-18.

9. Ozmert E, Erdem G, Topcu M, et al. Long-term follow-up of indirect hyperbilirubinemia in full-term Turkish infants. Acta Paediatr. 1996;85:1440-4. [CrossRef]

10. Harris MC, Bernbaum JC, Polin JR, Zimmerman R, Polin RA. Developmental follow-up of breastfed term and near-term infants with marked hyperbilirubinemia. Pediatrics. 2001;107:1075-80. [CrossRef]

11. Penn AA, Enzmann DR, Hahn JS, Stevenson DK. Kernicterus in a full term infant. Pediatrics. 1994;93(6 Pt 1):1003-6.

12. Lenhardt ML, McArtor R, Bryant B. Effects of neonatal hyperbilirubinemia on the brainstem electric response. J Pediatr. 1984;104:281-4. [CrossRef]

13. Streletz LJ, Graziani LJ, Branca PA, Desai HJ, Travis SF, Mikaelian DO. Brainstem auditory evoked potentials in fullterm and preterm newborns with hyperbilirubinemia and hypoxemia. Neuropediatrics. 1986;17:66-71. [CrossRef]

14. Rhee CK, Park HM, Jang YJ. Audiologic evaluation of neonates with severe hyperbilirubinemia using transiently evoked otoacoustic emissions and auditory brainstem responses. Laryngoscope. 1999;109:2005-8. [CrossRef]

15. Olds C, Oghalai JS. Audiologic impairment associated with bilirubin-induced neurologic damage. Semin Fetal Neonatal Med. 2015;20:42-6. [CrossRef]

16. Saluja S, Agarwal A, Kler N, Sanjiv A. Auditory neuropathy spectrum disorder in late preterm and term infants with severe jaundice Int J Pediatr Otorhinolaryngol. 2010;74:1292-7. [CrossRef]

17. Deliac P, Demarquez JL, Barberot JP, Sandler B, Paty J. Brainstem auditory evoked potentials in icteric fullterm newborns: alterations after Exchange transfusion. Neuropediatrics. 1990;21:115-8. [CrossRef]

18. Shapiro SM, Popelka GR. Auditory impairment in infants at risk for bilirubin-induced neurologic dysfunction. Semin Perinatol. 2011;35:162-70. [CrossRef]

19. Stein LK. Factors influencing the efficacy of üniversal newborn hearing screening. Pediatr Clin North Am. 1999;46:95-105. [CrossRef]

20. Oğün B, Serbetçioğlu B, Duman N, Ozkan H, Kirkim G. Long-term outcome of neonatal hyperbilirubinaemia: subjective and objective audiological measures. Clin Otolaryngol Allied Sci. 2003;28:507-13. [CrossRef] 
21. Duman N, Ozkan H, Serbetcioglu B, Ozgun B, Kumral A, Avcı M. Long-term follow-up of otherwise healthy term infants with marked hyperbilirubinaemia: should the limits of exchange transfusion be changed in Turkey? Acta Paediatr. 2004;93:361-7. [CrossRef]

22. Deorari AK, Singh M, Ahuja GK, et al. One year outcome of babies with severe neonatal hyperbilirubinemia and reversible abnormality in brainstem auditory evoked responses. Indian Pediatr. 1994;31:915-21.

23. Gupta AK, Mann SB. Is auditory brainstem response a bilirubin neurotoxicity marker? Am J Otolaryngol. 1998; 19:232-6. [CrossRef]

24. Vohr BR, Karp D, O'Dea C, et al. Behavioral changes correlated with brain-stem auditory evoked responses in term infants with moderate hyperbilirubinemia. J Pediatr. 1990;117(2 Pt 1):288-91. [CrossRef]

25. De Vries LS, Lary S, Whitelaw AG, Dubowitz LM. Relationship of serum bilirubin levels and hearing impairment in newborn infants. Early Hum Dev. 1987;15:269-77. [CrossRef]

26. Newman TB, Klebanoff MA. Neonatal hyperbilirubinemia and long-term outcome: another look at the Collaborative Perinatal Project. Pediatrics. 1993;92:651-7.

27. Scheidt PC, Mellits ED, Hardy JB, Drage JS, Boggs TR. Toxicity to bilirubin in neonates: infant development during first year in relation to maximum neonatal serum bilirubin concentration. J Pediatr. 1977;91:292-7. [CrossRef]

28. Kuriyama $M$, Konishi $Y$, Mikawa $H$. The effect of neonatal hyperbilirubinemia on the auditory brainstem response. Brain Dev. 1986;8:240-5. [CrossRef]

29. Funato M, Teraoka S, Tamai H, Shimida S. Follow-up study of auditory brainstem responses in hyperbilirubinemic newborns treated with exchange transfusion. Acta Paediatr Jpn. 1996;38:17-21. [CrossRef]

30. Wisnowski JL, Panigrahy A, Painter MJ, Watchko JF. Magnetic resonance imaging of bilirubin encephalopathy: current limitations and future promise. Semin Perinatol. 2014;38:422-8. [CrossRef]

31. Gökçay G, Boran P, Çiprut A, Bağlam T. The current situation in childhood hearing screening in our country and around the world. Çocuk Sağlığı ve Hastalıkları Dergisi. 2014;57:265-73. 